\title{
ANALISIS JUMLAH PASIEN MENGGUNAKAN EXPONENTIAL SMOOTHING TERHADAP EFISIENSI RAWAT INAP BERDASARKAN GRAFIK BARBER JOHNSON
}

\author{
Sakti Aktarim ${ }^{1}$, Achi Rinaldi ${ }^{* 2}$, Muhamad Syazali ${ }^{3}$ \\ 1,2Program Studi Pendidikan Matematika, Universitas Islam Negeri Raden Intan Lampung \\ 3Program Studi Matematika, Universitas Pertahanan Indonesia \\ *email korespondensi : achi@radenintan.ac.id
}

Diterima : (21-10-2021), Revisi: (05-12-2021), Diterbitkan : (09-12-2021)

\begin{abstract}
ABSTRAK
Penelitian ini bertujuan untuk menentukan model matematika terbaik yang dapat digunakan untuk menghitung tingkat efisiensi rawat inap selama dua tahun kedepan menggunakan metode exponential smoothing dan memprediksi jumlah pasien selama dua tahun kedepan berdasarkan grafik Barber Johnson di Rumah Sakit Pertamina Bintang Amin. Penelitian ini menggunakan data pasien dari bulan Januari 2017 sampai bulan Agustus 2021 dan empat bulan data Sensus Harian Rumah Sakit (SHRI). Perhitungan jumlah pasien dua tahun kedepan dari bulan September 2021 sampai bulan Agustus 2023 menggunakan aplikasi $R$ Studio dengan metode exponential smoothing, sedangkan metode grafik Barber Johnson untuk menentukan titik efisiensi rawat inap menggunakan microsoft excel. Model matematika yang diperoleh dari analisis data adalah $106 x+27 y=o$ dengan hasil ramalan jumlah pasien menggunakan exponential smoothing selama dua tahun kedepan dengan rata-rata 466 pasien dan grafik Barber Johnson yang menentukan titik efisensi rawat inap per bulan. Nilai rata-rata tempat tidur terpakai selama dua tahun kedepan adalah 35,46\%, maka selama dua tahun kedepan tingkat efisiensi rawat inap tidak efisien kerena nilai rata-rata keterpakaian tempat tidur selama dua tahun kedepan tidak mencapai $70 \%$.
\end{abstract}

Kata kunci : Jumlah Pasien, Efisiensi Rawat Inap, Ramalan Exponential Smoothing, Grafik Barber Johnson 


\begin{abstract}
This study aims to determine the best mathematical model that can be used to calculate the efficiency level of hospitalization for the next two years using the method exponential smoothing and predict the number of patients for the next two years based on the chart Barber Johnson at Pertamina Bintang Amin Hospital. This study uses patient data from January 2017 to August 2021 and four months of Hospital Daily Census (SHRI) data. Calculation of the number of patients for the next two years from September 2021 to August 2023 uses the $R$ Studio application with the exponential smoothing method, while the graph method Barber Johnson to determine the point of hospitalization efficiency uses microsoft excel. The results of the analysis can be concluded that the mathematical model obtained is $106 x+27 y=o$ with the results of forecasting the number of patients using exponential smoothing for the next two years with an average of 466 patients and the chart Barber Johnson which determines the efficiency point of hospitalization per month . It is known that the average value of beds used for the next two years is $35.46 \%$, so for the next two years the efficiency level of hospitalization is not efficient because the average value of beds used for the next two years does not reach $70 \%$.
\end{abstract}

Keywords : Number of Patients, Inpatient Efficiency, Forecast Exponential Smoothing, Barber Johnson Chart

\title{
Pendahuluan
}

Rumah Sakit merupakan organisasi pelayanan kesehatan yang sangat penting bagi masyarakat (Astuti \& Lesmana, 2018; Kusumawati et al., 2021). Saat ini rumah sakit menghadapi wabah Coronavirus Disease 2019 (Covid-19). Covid-19 atau virus corona diduga pertama kali berkontak dengan manusia di Wuhan, China pada 17 November 2019 (Suryani, 2021), dan ditemukan di Indonesia pertama kali pada 2 Maret 2020. Pemerintah Indonesia segera menindaklanjuti Standard Operating Procedure (SOP) dalam mengatasi penyebaran virus corona (Karim, 2020). Muncul berbagai penelitian terkait virus corona dari berbagai bidang keilmuan salah satunya pada bidang matematika, yaitu memprediksi peningkatan jumlah pasien yang akan datang ke rumah sakit (Utami et al., 2021).

Prediksi atau peramalan jumlah pasien di rumah sakit dapat dilakukan dengan menggunakan peramalan matematika. Salah satu metode peramalan adalah exponential smoothing (Lawalata et al., 2022) yang dipilih karena dapat dipergunakan secara luas dalam peramalan, sederhana, efisien dalam perhitungan, mudah disesuaikan dengan perubahan data, dan ketelitian metode ini cukup besar (Putro 
et al., 2018; Aden \& Supriyanti, 2020). Metode exponential smoothing adalah suatu prosedur perhitungan secara terus menerus yang menggunakan data terbaru (Arridho \& Astuti, 2020; Sudibyo et al., 2020). Penggunaan metode exponential smoothing mengurangi masalah penyimpanan data dalam jumlah besar, sehingga tidak perlu menyimpan semua data historis, tidak perlu menyimpan nilai pengamatan terakhir, ramalan terakhir, dan suatu nilai konstanta yang harus disimpan (Hakimah et al., 2020).

Prinsip dari metode exponential smoothing adalah menggunakan nilai pemulusan secara exponential sebagai ramalan nilai masa mendatang (Landia, 2020; Santiari \& Rahayuda, 2020), serta menunjukkan bahwa bobot menurun secara exponential pada data sebelum masa lalu (Mursidah et al., 2021). Metode ini merupakan peramalan yang cukup bagus untuk peramalan jangka menengah dan peramalan jangka panjang (Bagus \& Diksa, 2021). Perhitungan metode exponential smoothing pada peramalan jumlah pasien di rumah sakit dilakukan dengan menggunakan data pasien terdahulu, yang disebut rekam medis (Nurdiansyah, 2021), yang kemudian diolah sehingga berguna untuk mencari informasi tentang data yang ada (Hendrawan et al., 2014).

Pasien rawat inap memerlukan fasilitas kamar inap yang memadai untuk menunjang tingkat kepuasan pasien, salah satunya adalah tempat tidur (Widjaya et al., 2021). Tempat tidur dirancang khusus untuk pasien rawat inap atau orang lain yang membutuhkan suatu perawatan kesehatan (Sari et al., 2021). Kebutuhan tempat tidur bagi pasien rawat inap juga perlu dipersiapkan. Hal ini menjadi salah satu poin penting untuk mengukur tingkat efisiensi rawat inap. Salah satu metode untuk mengukur tingkat efisiensi rawat inap adalah Grafik Barber Johnson.

Grafik Barber Johnson merupakan visualisasi yang dapat menyajikan dengan jelas tingkat efisiensi pengelolaan rumah sakit dalam bentuk grafik (Valentina, 2019; Rizaldy et al., 2021). Penggunaan grafik Barber Johnson merupakan suatu upaya untuk mendayagunakan statistik Rumah Sakit dalam rangka memenuhi kebutuhan manajemen akan efisiensi pengelolaan dengan menggunakan indikator atau parameter tingkat efisiensi rumah sakit (Farmani \& Kartika, 2020; Azmi \& Putri, 2021). Selain itu grafik Barber Johnson juga digunakan untuk mengetahui tingkat efisiensi pelayanan rumah sakit (Rinjani \& Triyanti, 2016). Tingkat efisiensi rawat inap harus diolah terlebih dahulu ke dalam indikator rawat inap (BOR, LOS, TOI dan BTO) yang berfungsi untuk memantau kegiatan yang ada di unit rawat in- 
ap (Seha et al., 2020). Data dari indikator rawat inap dituangkan dalam grafik Barber Johnson yang digunakan untuk memantau dan menilai tingkat efisiensi pelayanan rawat inap (Defiyanti et al., 2021). Jika titik Barber Johnson berada di luar daerah efisiensi, maka layanan medis tidak efisien. Oleh karena itu, titik Barber Johnson digunakan untuk mengetahui tingkat efisiensi pelayanan kesehatan rumah sakit.

Berdasarkan uraian di atas, dilakukan penelitian dengan tujuan menentukan model matematika terbaik yang dapat digunakan untuk menghitung tingkat efisiensi rawat inap selama dua tahun kedepan dalam bentuk peramalan. Peramalan jumlah pasien rawat inap yang akan datang dilakukan dengan metode exponential smoothing dalam kurun waktu dua tahun dari bulan September 2021 sampai bulan Agustus 2023, kemudian dihubungkan dengan efisiensi tempat tidur berdasarkan grafik Barber Johnson.

\section{Metode Penelitian}

Penelitian ini bertujuan untuk mendapatkan model runtun waktu menggunakan metode exponential smoothing dan memprediksi jumlah pasien selama dua tahun ke depan berdasarkan grafik Barber Johnson. Data yang digunakan pada penelitian ini yaitu data pasien rawat inap per bulan dari bulan Januari tahun 2017 sampai bulan Agustus tahun 2021 pada Rumah Sakit Pertamina Bintang Amin. Sebaran data disajikan pada tabel berikut.

Tabel 1. Data Jumlah Pasien di Rumah Sakit Bintang Amin

\begin{tabular}{cccccc}
\hline & $\mathbf{2 0 1 7}$ & $\mathbf{2 0 1 8}$ & $\mathbf{2 0 1 9}$ & $\mathbf{2 0 2 0}$ & $\mathbf{2 0 2 1}$ \\
\hline Januari & 1149 & 919 & 936 & 1065 & 607 \\
Februari & 1045 & 865 & 973 & 1223 & 506 \\
Maret & 1115 & 986 & 1104 & 1104 & 654 \\
April & 1052 & 976 & 1148 & 456 & 694 \\
Mei & 1041 & 987 & 1010 & 367 & 651 \\
Juni & 733 & 692 & 720 & 566 & 725 \\
Juli & 982 & 987 & 907 & 649 & 500 \\
Agustus & 980 & 885 & 843 & 547 & 514 \\
September & 969 & 904 & 907 & 535 & - \\
Oktober & 1112 & 882 & 1157 & 576 & - \\
November & 1072 & 806 & 1018 & 748 & - \\
Desember & 1008 & 914 & 895 & 656 & - \\
\hline
\end{tabular}


Data yang dikumpulkan berupa jumlah pasien dan tempat tidur pasien. Data yang telah dikumpulkan selanjutnya di analisis dengan langkah-langkah :

1. Menginput dan memplot data jumlah pasien

2. Mencari nilai error terkecil menggunakan SSE (Sum of Square error)

3. Menentukan metode exponential smoothing

4. Menghitung hasil ramalan jumlah pasien

5. Menghitung parameter Barber Johnson

6. Membuat grafik Barber Johnson

7. Memasukkan nilai parameter Barber Johnson ke dalam grafik

8. Membuat model matematika

Pengolahan data metode exponential smoothing dilakukan dengan aplikasi $R$ Studio sedangkan penyajian grafik Barber Johnson dilakukan dengan aplikasi microsoft excel.

\section{Hasil dan Pembahasan}

Pada bagian ini menjelaskan proses pembentukan model ramalan dengan memeriksa nilai eror yang paling kecil antara single exponential smoothing, double exponential smoothing, dan triple exponential smoothing menggunakan SSE (Sum of Squared errors). Penentuan nilai SSE dan plot nilai SSE dilakukan menggunakan aplikasi $R$ Studio dengan langkah-langkah berikut.

1. Input data ke dalam $R$ studio dengan mengimpor data menggunakan package time series (ts).

2. Definisikan data dengan menulis :

library (time series)

lap =Data. Jumlah. Pasien

lap $=$ ts $($ lap, start $=c(2017,1)$, end $=c(2021,8)$, frequency $=12)$

lap

3. Plot data jumlah pasien

4. Single Exponential Smoothing

lapfore1 = Holtwinters (lap, beta =FALSE, gamma =FALSE)

lapfore1

lapfore1 \$SSE

plot (lapfore1)

Dengan nilai $\alpha=533,7828$ dan nilai SSE $=1331563$ 
5. Double Exponential Smoothing

lapfore2 $=$ Holtwinters (lap, gamma $=$ FALSE)

lapfore2

lapfore $2 \$ S S E$

plot (lapfore2)

Dengannilai $\alpha=515,95937$, nilai $\beta=-16,82247$ dan nilai SSE $=151249$

6. Triple Exponential Smoothing

lapfore3 = Holtwinters (lap)

lapfore3

lapfore 3 SSE

plot (lapfore3)

Dengan nilai $\alpha=0,8051339$, nilai $\beta=0$, nilai $\Upsilon=1$ dan nilai SSE $=1289613$

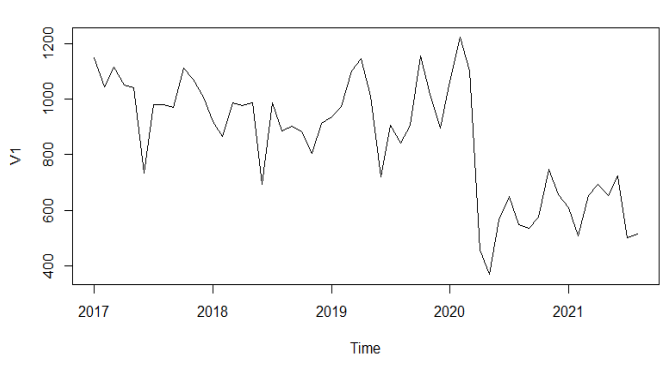

Plot Data JumlahPasien

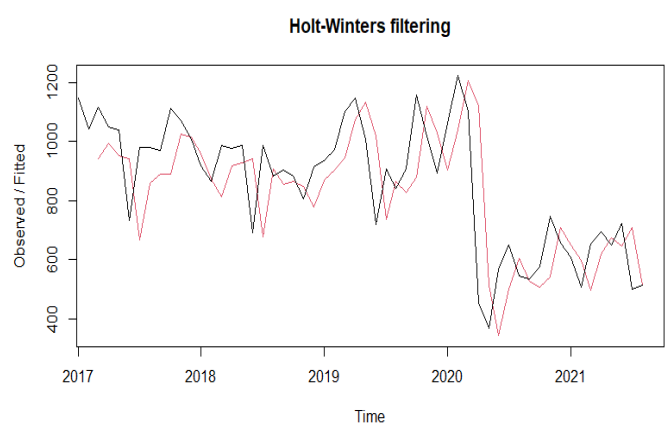

Plot Double Exponential Smoothing

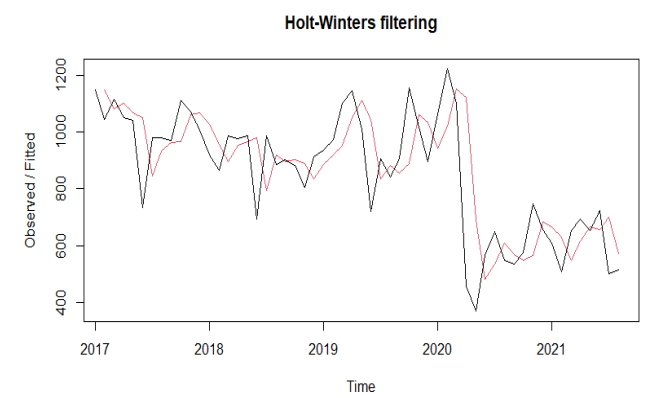

Plot Single Exponential Smoothing

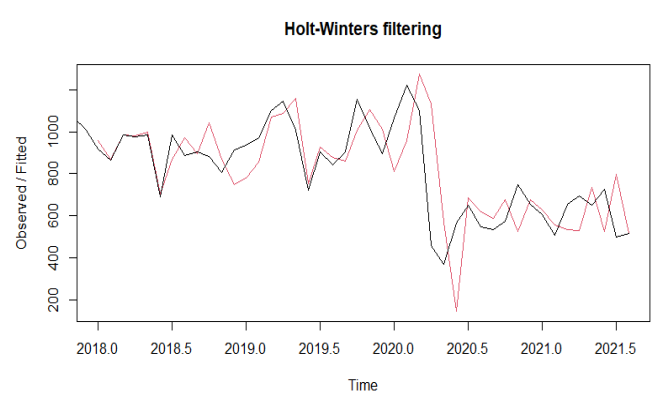

Plot Triple Exponential Smoothing

Gambar 1. Pembentukan Model Ramalan

Berdasarkan gambar di atas, diperoleh SSE (Sum of Squared errors) pada single exponential smoothing sebesar 1331563, double exponensial smoothing sebesar 1512492, dan triple exponensial smoothing sebesar 1289612. Sehingga dapat disimpulkan bahwa nilai SSE yang paling kecil terjadi pada triple exponential smooth- 
ing.

Selanjutnya digunakan rumus triple exponential untuk meramalkan jumlah pasien. Algoritma dan plot nilai ramalan jumlah pasien dilakukan dengan aplikasi $R$ Studio sebagai berikut.

1. Masukan rumusTriple Exponential Smoothing

Predict (lapfore3), n.ahead $=24$ )

2. Kemudian plot hasil ramalan

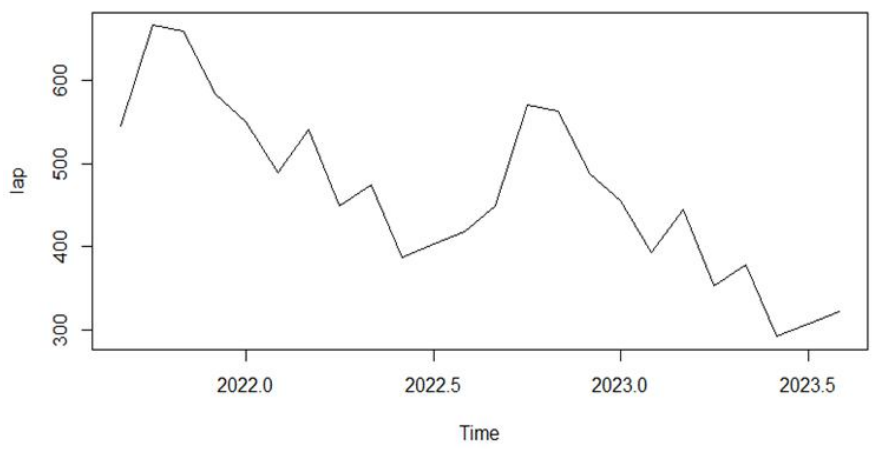

Gambar 2. Plot Nilai Ramalan Jumlah Pasien

Berdasarkan gambar di atas, dapat disimpulkan bahwa nilai ramalan jumlah pasien terbanyak terdapat pada rentang tahun 2021-2022 dan paling sedikit yaitu pada rentang tahun 2023.

Setelah mengetahui nilai ramalan jumlah pasien dengan metode exponential smoothing, selanjutnya dibuat grafik Barber Johnson untuk mengetahui nilai efisiensi rawat inap.
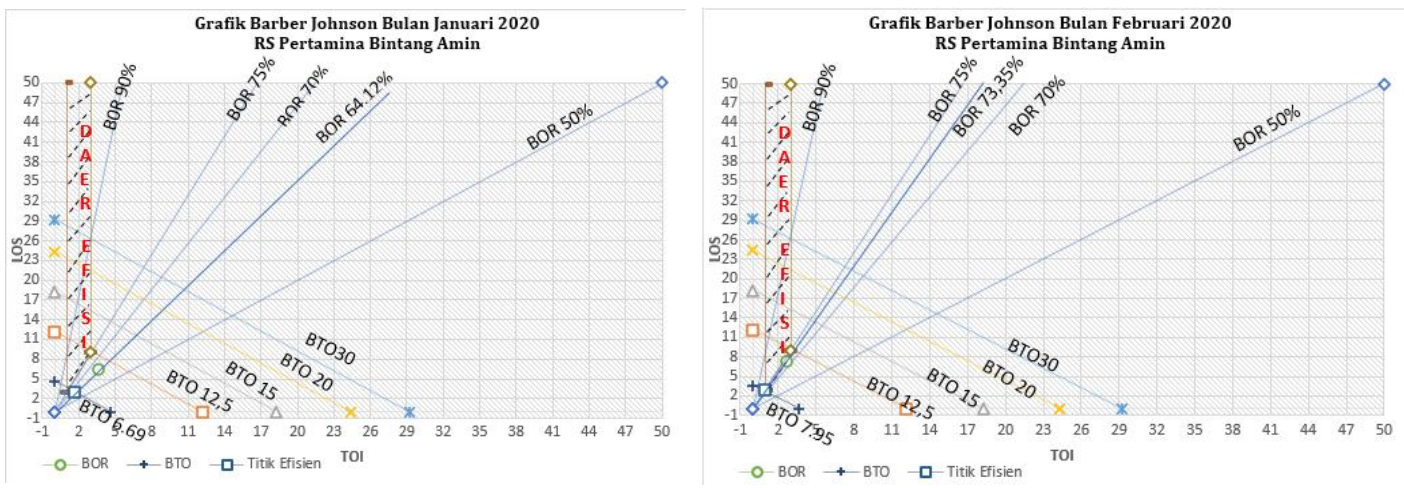

Gambar 3. Grafik Efisiensi Rawat Inap Bulan Januari-Februari 2020

Dari grafik di atas, dapat dilihat bahwa pada bulan Januari 2020 titik efisien belum berada pada daerah efisien, karena nilai BOR (Bed Occupancy Rate) belum memenuhi nilai efisiensi rawat inap, sedangkan pada bulan Februari 2020 titik efi- 
sien berada pada daerah efisien, karena nilai BOR (Bed Occupancy Rate) memenuhi nilai efisiensi rawat inap. Sehingga dapat disimpulkan bahwa pada bulan Februari 2020 penggunaan tempat tidur di Rumah Sakit Pertamina Bintang Amin sudah efisien dengan persentase sebesar 73,35\%, sedangkan pada Januari 2020 penggunaan tempat tidur di Rumah Sakit Pertamina Bintang Amin belum efisien dengan persentase sebesar $64,12 \%$.

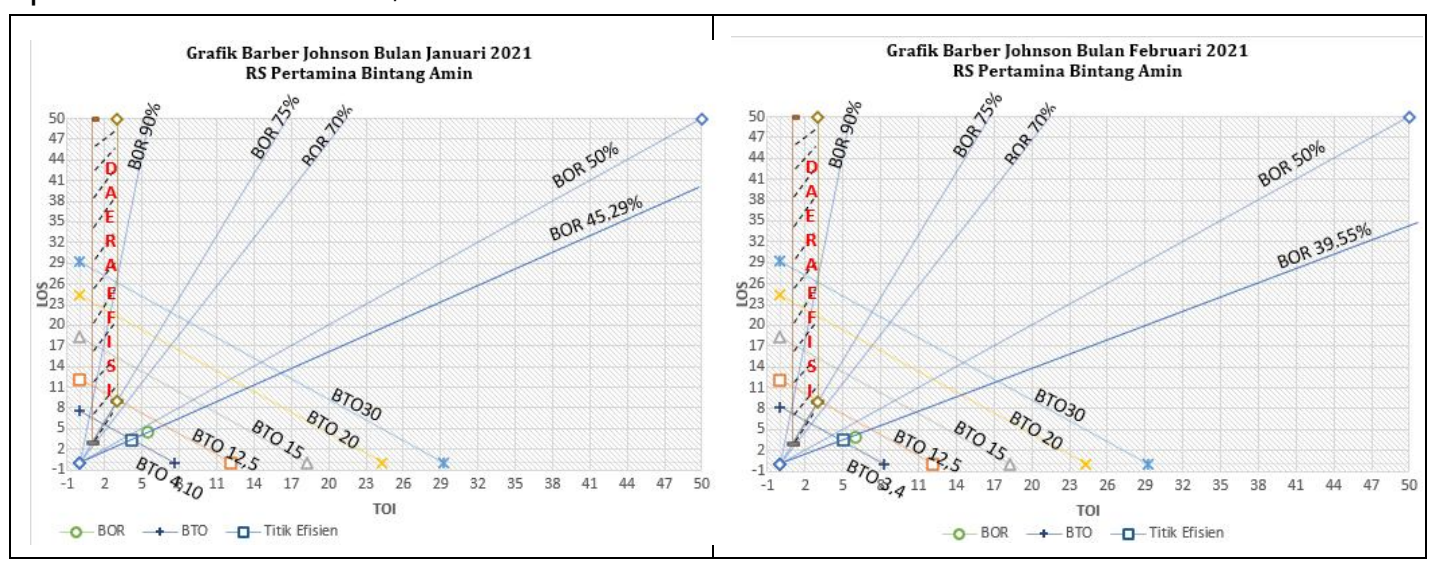

Gambar 4. Grafik Efisiensi Rawat Inap Bulan Januari-Februari 2021

Dari grafik di atas, dapat dilihat bahwa pada bulan Januari-Februari 2021 titik efisien belum berada pada daerah efisien, karena nilai BOR (Bed Occupancy Rate) belum memenuhi nilai efisiensi rawat inap. Sehingga dapat disimpulkan bahwa pada bulan Januari-Februari 2021 penggunaan tempat tidur di Rumah Sakit Pertamina Bintang Amin belum efisien karena persentase cukup rendah yaitu 45,29\% dan $39,55 \%$

Berdasarkan hasil ramalan exponential smoothing selama dua tahun kedepan diketahui bahwa jumlah pasien di Rumah Sakit Pertamina Bintang Amin mengalami penurunan. Berikut sebaran data jumlah pasien dan hasil ramalan jumlah pasien. 
Tabel 2. Data Jumlah Pasien dan Hasil Ramalan Jumlah Pasien

\begin{tabular}{cccccccc}
\hline & $\mathbf{2 0 1 7}$ & $\mathbf{2 0 1 8}$ & $\mathbf{2 0 1 9}$ & $\mathbf{2 0 2 0}$ & $\mathbf{2 0 2 1}$ & $\mathbf{2 0 2 2}$ & $\mathbf{2 0 2 3}$ \\
\hline Januari & 1149 & 919 & 936 & 1065 & 607 & 551 & 455 \\
Februari & 1045 & 865 & 973 & 1223 & 506 & 490 & 394 \\
Maret & 1115 & 986 & 1104 & 1104 & 654 & 542 & 445 \\
April & 1052 & 976 & 1148 & 456 & 694 & 449 & 353 \\
Mei & 1041 & 987 & 1010 & 367 & 651 & 475 & 379 \\
Juni & 733 & 692 & 720 & 566 & 725 & 388 & 292 \\
Juli & 982 & 987 & 907 & 649 & 500 & 403 & 307 \\
Agustus & 980 & 885 & 843 & 547 & 514 & 418 & 322 \\
September & 969 & 904 & 907 & 535 & 546 & 450 & - \\
Oktober & 1112 & 882 & 1157 & 576 & 667 & 571 & - \\
November & 1072 & 806 & 1018 & 748 & 661 & 564 & - \\
Desember & 1008 & 914 & 895 & 656 & 584 & 488 & - \\
\hline
\end{tabular}

Dari data di atas dapat diketahui bahwa hasil ramalan selama dua tahun ke depan masih berada pada sebaran data yang terdampak wabah virus corona dan mempengaruhi laju perkembangan data pasien rawat inap. Turunnya jumlah pasien akan mengakibatkan turunnya penggunaan tempat tidur ke titik efisien pada grafik Barber Johnson.

Berdasarkan grafik Barber Johnson di Rumah Sakit Pertamina Bintang Amin dua bulan sebelum wabah virus corona dan dua bulan saat wabah corona, dapat diketahui bahwa hanya satu bulan terjadi efisiensi rawat inap pada titik efisien dan tiga bulan lainnya dengan efisiensi rawat inap tidak berada pada titik efisien. Berikut adalah sebaran nilai Barber Johnson dalam empat bulan tersebut.

Tabel 3. Nilai Barber Johnson dalam Empat Bulan

\begin{tabular}{ccccc}
\hline Indikator & Januari 2020 & Februari 2020 & Januari 2021 & Februari 2021 \\
\hline BOR & $64,12 \%$ & $73,35 \%$ & $45,29 \%$ & $39,55 \%$ \\
LOS & 2,88 & 2,89 & 3,3 & 3,49 \\
TOI & 1,66 & 0,97 & 4,14 & 4,98 \\
BTO & 6,69 & 7,95 & 4,1 & 3,4 \\
\hline
\end{tabular}

Tabel di atas menunjukkan bahwa hanya bulan Februari 2020 yang efisiensi rawat inapnya memiliki titik yang efisien dengan rata-rata penggunaan tempat tidur sebesar 73,35\%, 1223 pasien dan 173 tempat tidur. Pada bulan Januari 2020 wabah virus corona belum memasuki Indonesia tapi efisiensi rawat inap berada pada titik yang tidak efisien dengan rata-rata penggunaan tempat tidur sebesar 64,12\%, 1065 pasien dan 173 tempat tidur. Pada bulan ketiga dan keempat yang 
sudah memasuki wabah virus corona memiliki efisiensi rawat inap dengan titik yang tidak efisien yaitu bulan Januari 2021 dengan rata-rata penggunaan tempat tidur sebesar 45,29\%, 607 pasien dan 151 tempat tidur. Sedangkan pada bulan Februari 2021 dengan rata-rata penggunaan tempat tidur sebesar 39,55\%, 506 pasien dan 151 tempat tidur. Dari penjelasan di atas dapat dibuat tabel sebagai berikut.

Tabel 4. Nilai Efisiensi Rawat Inap

\begin{tabular}{lcccc}
\hline & Pasien & Tempat Tidur & $\begin{array}{c}\text { Rata-rata } \\
\text { Penggunaan } \\
\text { Tempat Tidur }\end{array}$ & Nilai Efisien \\
\hline Januari 2020 & 1065 & 173 & $64,12 \%$ & TidakEfisien \\
Februari 2020 & 1223 & 173 & $73,35 \%$ & Efisien \\
Januari 2021 & 607 & 151 & $45,29 \%$ & TidakEfisien \\
Februari 2021 & 506 & 151 & $39,55 \%$ & TidakEfisien \\
\hline
\end{tabular}

Tabel di atas menunjukkan bahwa jumlah pasien dan jumlah tempat tidur sangat berpengaruh untuk membuat rawat inap memiliki titik yang efisien. Jika jumlah pasien rawat inap sangat banyak dengan tempat tidur yang sedikit akan membuat rawat inap terlalu sibuk, dan menyebabkan rawat inap tidak memiliki titik yang efisien. Sedangkan jika pasien rawat inap memiliki jumlah yang sedikit dengan tempat tidur yang banyak maka akan membuat rawat inap tidak memiliki titik yang efisien. Terlihat dari tabel di atas dengan 1223 pasien dan 173 tempat tidur memiliki nilai yang efisien, sedangkan 1065 pasien dengan jumlah tempat tidur yang sama memiliki nilai yang tidak efisien. Berarti jika ingin membuat rawat inap yang efisien dengan jumlah tempat 173 harus memiliki pasien kurang dari 1223 pasien dan lebih dari 1065 pasien.

Untuk membuat rawat inap yang efisien dengan jumlah tempat tidur 151 harus memiliki pasien yang jauh melebihi 1223 pasien. Jika nilai ramalan jumlah pasien selama dua tahun ke depan menunjukkan rata-rata sebanyak 466 pasien, maka selama dua tahun ke depan dengan jumlah tempat tidur 151 akan membuat efisiensi rawat inap tidak berada pada titik efisien selama dua tahun kedepan. Sehingga dibuat model matematika yang dapat digunakan untuk mengetahui efisiensi rawat inap serta nilai rata-rata keterpakaian tempat tidur.

Jika $x$ menunjukkan jumlah pasien, $y$ menunjukkan tempat tidur yang tersedia, $a$ adalah koefisien $x, b$ adalah koefisien $y$, dan $o$ menunjukkan rata-rata tempat tidur yang terpakai, maka model matematika yang diperoleh adalah 


$$
a x+b y=o
$$

Pada bulan Januari 2021 diketahui $x=607, y=151$, dan $o=68.387$. Maka dapat diperoleh persamaan

$$
607 a+151 b=68.387
$$

Pada bulan Februari 2021 diketahui $x=506, y=151$, dano $=$ 57.714. Maka dapat diperoleh persamaan

$$
506 a+151 b=57.714
$$

Melalui eliminasi persamaan 1 dan persamaan 2 dapat diperoleh nilai $a=106$ dan $b=27$. Akibatnya dapat diperoleh model matematika

$$
106 x+27 y=o
$$

Selanjutnya dilakukan perhitungan ramalan nilai rata-rata tempat tidur terpakai menggunakan model matematika. Pada bulan September 2021 diketahui $x=546$ dan $y=151$. Akibatnya rata-rata tempat tidur terpakai dapat ditentukan sebesar $o=61.953$.

Sedangkan BOR (Bed Occupancy Rate) bulan September 2021 dapat ditentukan sebagai $B O R=\frac{61.953}{151} \times 100 \%=41,03 \%$. Nilai tersebut dinyatakan belum efisien. Untuk itu dilakukan perhitungan sampai pada Bulan Agustus 2023. Nilai ramalan rata-rata tempat tidur terpakai disajikan pada tabel berikut.

Tabel 5. Nilai Ramalan Rata-Rata Tempat Tidur Terpakai

\begin{tabular}{cccc}
\hline Bulan|Tahun & $\mathbf{2 0 2 1}$ & $\mathbf{2 0 2 2}$ & $\mathbf{2 0 2 3}$ \\
\hline Januari & & $41,38 \%$ & $34,64 \%$ \\
Februari & & $37,10 \%$ & $30,36 \%$ \\
Maret & & $40,68 \%$ & $33,94 \%$ \\
April & & $34,22 \%$ & $27,48 \%$ \\
Mei & $36,05 \%$ & $29,31 \%$ \\
Juni & $29,94 \%$ & $23,20 \%$ \\
Juli & $30,99 \%$ & $24,86 \%$ \\
Agustus & & $32,05 \%$ & $25,31 \%$ \\
September & $41,03 \%$ & $34,29 \%$ & \\
Oktober & $49,52 \%$ & $42,78 \%$ & \\
November & $49,03 \%$ & $42,30 \%$ & \\
Desember & $43,70 \%$ & $36,96 \%$ & \\
\hline
\end{tabular}

Berdasarkan tabel di atas, dapat diketahui bahwa tidak ada nilai ramalan rata-rata tempat tidur terpakai yang mencapai 70\%, artinya dari bulan September 2021 sampai bulan Agustus 2023 rawat inap tidak efisien. Untuk membuat rawat 
inap efisien nilai rata-rata tempat tidur terpakai harus mencapai 70\% sampai $80 \%$. Tidak efisiennya rawat inap di Rumah Sakit Pertamina Bintang Amin salah satunya dikarenakan wabah virus corona. Di Rumah Sakit Bintang Amin pada awalnyamembuka 25 ruang isolasi dengan 25 tempat tidur. Seiring bertambahnya pasien covid-19 maka pihak rumah sakit menambah ruang isolasi menjadi 51 ruangan dengan 51 tempat tidur dari 151 tempat tidur. Karena pasien covid-19 meningkat sangat pesat maka ruang isolasi hampir selalu penuh, berbanding terbalik dengan ruang pasien non covid-19.

Hasil analisis jumlah pasien menggunakan exponential smoothing terhadap efisiensi rawat inap berdasarkan grafik Barber Johnson menunjukkan bahwa rawat inap selama dua tahun ke depan belum efisien. Sehingga pihak Rumah Sakit Pertamina Bintang Amin perlu melakukan penanganan wabah virus corona secara maksimal, selalu memperbaiki pelayanan medis dari waktu ke waktu agar pasien merasa puas setelah berobat, pendapatan yang diperoleh rumah sakit harus diatur baik yang berasal dari pasien rawat jalan, rawat inap, kamar operasi dan sebagainya. Pihak rumah sakit juga harus salalu mengawasi fasilitas rumah sakit setiap bulan, terkait sarana prasarana yang perlu diperbaiki atau ditambah atau diganti atau masih layak dipakai. Selain itu sistem yang dipakai dalam menjalankan kegiatan sehari-hari harus dilakukan dengan prosedur yang baik. Perlu juga kiranya ditingkatkan hubungan dengan rumah sakit lain, serta mengadakan training atau simposium dengan mengundang tenaga dokter dari rumah sakit lain.

\section{Kesimpulan}

Berdasarkan analisis data diperoleh model matematika yang sesuai adalah $106 x+27 y=o$ dengan hasil ramalan jumlah pasien menggunakan exponential smoothing selama dua tahun ke depan dengan rata-rata 466 pasien dan grafik Barber Johnson yang menentukan titik efisen rawat inap per bulanNilai rata-rata penggunaan tempat tidur yang terpakai dari bulan September 2021 sampai bulan Agustus 2023 menunjukkan bahwa rawat inap tidak efisien, karena nilai rata-rata penggunaan tempat tidur yang terpakai tidak mencapai 70\%. Berdasarkan hasil tersebut pihak rumah sakit dapat merencanakan berbagai upaya untuk membuat rawat inap kembali efisien pada dua tahun mendatang. Penelitian ini juga dapat dikembangkan dengan melakukan peramalan pada data-data yang lain yang relevan dengan metode exponensial smoothing dan grafik Barber Johnson. 


\section{Daftar Pustaka}

Aden, A., \& Supriyanti, A. (2020). Prediksi Jumlah Calon Peserta Didik Baru Menggunakan Metode Double Exponential Smoothing Dari Brown:(Study Kasus: SD Islam Al-Musyarrofah Jakarta). Jurnal Lebesgue: Jurnal Ilmiah Pendidikan Matematika, Matematika Dan Statistika, 1(1), 56-62. https:/ / doi.org/ 10.46306/ lb.v1i1

Arridho, M. N., \& Astuti, Y. (2020). Penerapan Metode Single Exponential Smoothing untuk Memprediksi Penjualan Katering pada Kedai Pojok Kedaung. Jurnal Ilmiah Intech: Information Technology Journal of UMUS, 2(2), 35-44. https:/ / doi.org/ 10.46772/ intech.v2i02.288

Astuti, R., \& Lesmana, O. P. A. (2018). Pengaruh Motivasi dan Beban Kerja terhadap Kinerja Perawat pada Rumah Sakit Umum Mitra Medika Medan. Jurnal Ilman, 6(2), 42-50.

Azmi, Z., \& Putri, H. N. (2021). Literature Review Pelaporan Internal Berupa Grafik Barber Jhonson. Administrasi \& Health Information of Journal, 2(2), 332-337.

Bagus, I. G., \& Diksa, N. (2021). Peramalan Gelombang Covid 19 Menggunakan Hybrid Nonlinear Regression Logistic - Double Exponential Smoothing di Indonesia dan Prancis. Jambura J. Math., 3(1), 37-51.

Defiyanti, R. S. P., Setiatin, S., \& Susanto, A. (2021). Analisis Trend Dan Grafik Barber Johnson Pada Efisiensi Tempat Tidur Di Rumah Sakit X Kota Bandung. Jurnal Ilmiah Perekam Dan Informasi Kesehatan Imelda, 6(2), 119-130.

Farmani, P. I., \& Kartika, N. M. U. (2020). Analisis Efisiensi Pelayanan Rawat Inap di Rumah Sakit Umum Dharma Yadnya Pada Era JKN. Bali International Scientific Forum, 1(1), 1-11.

Hakimah, M., Rahmawati, W. M., \& Afandi, A. Y. (2020). Pengukuran Kinerja Metode Peramalan Tipe Exponential Smoothing Dalam Parameter Terbaiknya. Jurnal Ilmiah NERO (Network Engineering Research Operation), 5(1), 44-50. https:// doi.org/ 10.21107/ nero.v5i1.150

Hendrawan, V. Y., Winardi, S., \& Surbakti, H. (2014). Sistem Informasi Rekam Medis Rawat Jalan Dan Pemeriksaan Penunjang Diagnosa Berbasis Website (Studi Kasus : Rumah Sakit Khusus Bedah Klinik Sinduadi, Melati, Sleman, Yogyakarta). Teknologi Informasi, 9(27), 53-58.

Karim, Y. Y. dan M. A. (2020). Pemodelan Matematika Penyebaran Covid-19 Di Provinsi Kalimantan Selatan. JEDCHEM (Journal Education and Chemistry), 2(1), 3257-3264.

Kusumawati, F. T., Dwiantoro, L., \& Nurmalia, D. (2021). Psychological Wellbeing Perawat Igd Rumah Sakit Jiwa Dalam Masa Tugas Covid-19 : Studi Fenomenologi. Jurnal Surya Muda, 3(2), 76-101.

Landia, B. (2020). Peramalan Jumlah Mahasiswa Baru Dengan Exponential 
Smoothing dan Moving Average. Jurnal Ilmiah Intech : Information Technology Journal of UMUS, 2(1), 71-78. https:/ / doi.org/ 10.46772/ intech.v2i01.188

Lawalata, F., Sediyono, E., \& Purnomo, H. (2022). Analisis Prediksi Jumlah Pasien Rawat Inap di Rumah Sakit GMIM Siloam Sonder Menggunakan Metode Triple Exponential Smoothing. Jointer: Journal Of Informatics Engineering, 2(1), 32-36.

Mursidah, Yunina, Nurhasanah, \& Yuni, D. (2021). Perbandingan Metode Exponential Smoothing dan Metode Decomposition Untuk Meramalkan Persediaan Beras (Studi Kasus Divre Bulog Lhokseumawe). Jurnal Visioner \& Strategis, 10(1), 37-46.

Nugroho Arif Sudibyo, Ardymulya Iswardani, Arif Wicaksono Septyanto, \& Tyan Ganang Wicaksono. (2020). Prediksi Inflasi Di Indonesia Menggunakan Metode Moving Average, Single Exponential Smoothing Dan Double Exponential Smoothing. Jurnal Lebesgue : Jurnal Ilmiah Pendidikan Matematika, Matematika Dan Statistika, 1(2), 123-129. https:/ / doi.org/ 10.46306/ lb.v1i2.25

Nurdiansyah, D. (2021). Penerapan Model Exponential Smoothing berbasis Metode Evolutionary pada Kasus COVID 19 dan DBD di Bojonegoro. Jurnal Kesehatan Vokasional, 6(3), 174-181.

Putro, B., Furqon, M. T., \& Wijoyo, S. H. (2018). Prediksi Jumlah Kebutuhan Pemakaian Air Menggunakan Metode Exponential Smoothing. Jurnal Pengembangan Teknologi Informasi Dan Ilmu Komputer, 2(11), 4679-4686.

Rinjani, I., \& Triyanti, E. (2016). Analisis Efisiensi Penggunaan Tempat Tidur Per Ruangan Berdasarkan Indikator Depkes Dan Barber Johnson Di Rumah Sakit Singaparna Medika Citra Utama Kabupaten Tasikmalaya Triwulan 1 Tahun 2016. Jurnal Manajemen Informasi Kesehatan Indonesia, 4(1), 38-45. https:/ / doi.org/ 10.33560/.v4i2.130

Rizaldy, M. N. I., Maulana, R., \& Herfiyanti, L. (2021). Implementasi grafik barber johnson pada aplikasi microsoft excel di rsud cililin.Jurnal Kesehatan Tambusai, 2(September), 50-56.

Santiari, N. P. L., \& Rahayuda, I. G. S. (2020). Penerapan Metode Exponential Smoothing Untuk Peramalan Penjualan Pada Toko Gitar. JOINTECS (Journal of Information Technology and Computer Science), 5(3), 203-210. https:/ / doi.org/ 10.31328/ jointecs.v5i3.1520

Sari, M. T., Putri, M. E., \& Daryanto. (2021). Study Fenomenologi Pengalaman Perawat Dalam Memberikan Asuhan Keperawatan Pada Pasien Covid-19. Jurnal Ilmiah Universitas Batanghari Jambi, 21(3), 1176-1183. https:// doi.org/ 10.33087/ jiubj.v21i3.1725

Seha, H. N., Ratna, F., \& Nugroho, P. (2020). Efisiensi Indikator Rawat Inap Rs Rajawali Citra Tahun 2019. Prosiding Diskusi Ilmiah: Inovasi Dan Teknologi Informasi Untuk Mendukung Kinerja PMIK Dalam Masa Pandemi Covid 19 
Keamanan, 24-39.

Suryani, D. E. (2021). Perlindungan Hukum Terhadap Penetapan Status Covid-19 Pada Pasien Penyakit Umum Oleh Rumah Sakit Di Kota Medan Oleh: Jurnal Hukum Kaidah: Media Komunikasi Dan Informasi Hukum Dan Masyarakat, 20(2), 127-135.

Utami, Y. P. D., Pinzon, R. T., \& Meliala, A. (2021). Evaluasi Kesiapan Rumah Sakit Menghadapi Bencana Non-Alam: Studi Kasus Covid-19 Di Rumah Sakit Bethesda Yogyakarta. Jurnal Kebijakan Kesehatan Indonesia, 10(2), 100-106.

Valentina. (2019). Efisiensi Penggunaan Tempat Tidur Di Ruang Rawat Inap Berdasarkan Grafik Barber Johnson Di RSUD Dr. Pirngadi Medan. Jurnal Ilmiah Perekam Dan Informasi Kesehatan Imelda, 4(2), 598-603.

Widjaya, J. S., R, D. A., \& Sari, S. R. P. (2021). Sistem Prediksi Jumlah Pasien Covid-19 Menggunakan Metode Trend Least Square Berbasis Web. SISTEMASI: Jurnal Sistem Informasi, 10(1), 39-51. 